\title{
Lexis
}

Journal in English Lexicology

$8 \mid 2014$

Metaphor Studies in the English Language

\section{Power and Metaphor}

Towards more Executive Power in American Presidents' Inaugural Addresses?

\section{Rémi Digonnet}

\section{(2) OpenEdition}

Journals

\section{Electronic version}

URL: http://journals.openedition.org/lexis/224

DOI: 10.4000/lexis.224

ISSN: 1951-6215

\section{Publisher}

Université Jean Moulin - Lyon 3

\section{Electronic reference}

Rémi Digonnet, « Power and Metaphor », Lexis [Online], 8 | 2014, Online since 09 January 2014, connection on 30 April 2019. URL : http://journals.openedition.org/lexis/224 ; DOI : 10.4000/lexis.224

This text was automatically generated on 30 April 2019.

\section{(ब) $\odot \Theta \Theta$}

Lexis is licensed under a Creative Commons Attribution-NonCommercial-NoDerivatives 4.0 International License. 


\section{Power and Metaphor}

Towards more Executive Power in American Presidents' Inaugural Addresses?

\section{Rémi Digonnet}

\section{Introduction}

1 What emerges from the analysis of the evolution of power through a series of inaugural addresses by American presidents is a certain common ground between metaphor and politics. Often characterised by the transition from written language to speech, political discourse is driven by regular and specific communication skills. ${ }^{1}$ Recourse to metaphor appears as one of the most efficient processes to convey a political message. Metaphor is creative; similarly, political speeches signal change through their creativity. Metaphor allows recycling of language while political speeches tend to re-use and recycle old ideas and concepts. To be acknowledged as valuable and pertinent, a metaphor must be striking, as a good political speech must communicate striking and therefore memorable ideas to make a positive impression on the audience. This attractiveness applies both to metaphor in the Aristotelian tradition and political behaviour. In contrast, falsehood is rooted in metaphor as deception, which is disseminated through political speeches. In short, metaphor appears as the vital process for the composition of a political speech which takes on its essential aspects. Because of obvious similarities between the metaphorical process and the political process, metaphor is the keystone of political discourse.

2 The corpus chosen, the inaugural addresses by American presidents over an 80-year period, from F.D. Roosevelt's first address to B. Obama's second inaugural address, is pertinent for various reasons. First, such a speech represents the epitome of presidential power as it amounts to a powerful testimony as well as a testimony of power. On a national level, such a speech is a window on power in the United States for it is first step to leadership, the 'inaugural' access to power. On a global level, America appears as the leader of the world in terms of international power as the president addresses 
international concerns and attracts worldwide attention. This official and powerful speech alive is crucial as the first political test of the new president for millions of Americans. Firstly, as a regular milestone in the political agenda, the inaugural address is useful for the study of the evolution of power. Secondly, if the inaugural address format is inherently the expression of power, it can be expected that we will hear about the authority of one man though the voice of one man. As the new leader, the president speaks for himself about powers recently bestowed upon him. Executive power can then be assessed through inaugural speeches. Finally, the analysis of inaugural addresses harvests an abundance of metaphors, either lexicalised or creative, since the address in its rhetorical function is meant to be addressed to American citizens in an attempt to persuade them. As such, the inaugural address seems to provide a unique intersection of the rhetorical privilege of metaphor and the presidential discourse on power.

Through the study of various inaugural addresses, the powers of metaphor, either ornamental, cognitive, or political, will be highlighted before a thorough analysis of the metaphors of power, whether they be collective, individual, or even divine. Conjointly taking metaphor and power into consideration will eventually help answer the following question: do power metaphors reflect the increasing executive powers conferred on the president over this period?

\section{The powers of metaphor: a typology}

\subsection{Power of seduction}

4 The power of metaphor to charm its audience, recorded and analysed in the first theories on metaphor with Aristotle ${ }^{2}$ and Cicero, endures today and is particularly useful for political purposes. The faculty of captivating an audience remains one of the most powerful strengths of metaphor. Metaphor refers then to eloquence or delectatio, as coined by Cicero:

Au début, on imagina les vêtements pour se préserver du froid, puis on les mit pour donner au corps une parure pleine de noblesse; de même la métaphore (verbi translatio), fille de la pauvreté (inopia), se développa pour le plaisir (delectatio).

[Cicero, De Oratore, III, 37]

5 The pleasure of creating or hearing good metaphors is often paired with aesthetics of speech and more specifically the use of metaphors. The beauty of speech is supposed to be ornamental and metaphor is one of the best ornaments to cover the poverty of speech:

La métaphore aura aussi ses ennemis, qui, dans une interprétation qu'on peut dire

"cosmétique " aussi bien que "culinaire», ne verront en elle que simple ornement et que pure délectation. [Ricœur 1975: 16]

The charming function of metaphor is above all reserved for literary metaphors, creative metaphors and new metaphors. For the classical rhetoricians, poetry as well as political discourse are the ideal loci for metaphor, where the goal is to seduce and attract the audience through neatly-coined metaphors.

7 From the beauty of the alien word to the beauty of the mind, Aristotle was convinced that the creation of metaphors was due to a trait of genius. Though, far from an elitist perception of metaphor, Aristotle indicated the natural origin of true literary genius, stating that some people were better at coining good metaphors: 
It is a great matter to observe propriety in these several modes of expression compound words, strange (or rare) words, and so forth. But the greatest thing by far is to have a command of metaphor. This alone cannot be imparted by another; it is the mark of genius - for to make good metaphors implies an eye for resemblances. [Aristotle, Poetics 1458b; Butcher 31]

If the eye for resemblances has long been put to the fore through the analogical perception of metaphor (Aristotle, Dumarsais, Fontanier, Lakoff), a new perspective on metaphor based on an internal conflict (Prandi, Fauconnier) tends to shed light on a contrastive way to define a metaphor. Like the analogical/conflictual double identity of metaphor, the idea of seduction is ambiguous. If attractiveness and charm belong to the metaphor, deceit and falsity are also part of the seduction vehicled by metaphors. The power of seduction also means the power of deception: an internal deception through ontological conflicts in metaphor, an external deception with contextual conflicts, either exophoric or endophoric, between the metaphoric expression and the context. The political discourse is a good illustration of both aspects of the concept of seduction through metaphor, both appealing and deceitful. Attracting voters and disguising reality by giving another vision of reality are two resources well anchored in political addresses: "Slowly but surely we are weaving a world fabric of international security and growing prosperity” [Truman 1949].

\subsection{Power of perception}

9 From an ornament of the word to a new vision of the world, metaphor does more than simply adorn language. ${ }^{3}$ The initial literary process has increasingly given way to a cognitive process. The cognitive powers of metaphor initially indicated by Aristotle and emphasised by Lakoff and Johnson advocate for our understanding of the world:

Since much of our social reality is understood in metaphorical terms, and since our conception of the physical world is partly metaphorical, metaphor plays a very significant role in determining what is real for us. [Lakoff \& Johnson 1980: 146]

10 Both recent cognitive theories, i.e. the Conceptual Metaphor Theory and the Blending Theory, illustrate well the cognitive process of metaphor and the perceptive power of the latter. The CMT, by focusing mainly on conventional metaphors, brought to light the numerous underlying connections between domains and consequently exposed the powerful analogical web of metaphors to understand one domain in terms of another through mappings:

The metaphor involves understanding one domain of experience [...] in terms of a very different domain of experience [...]. More technically, the metaphor can be understood as a mapping (in the mathematical sense) from a source domain [...] to a target domain [...]. The mapping is tightly structured. [Lakoff 1993: 206-207]

11 The BT, mostly dedicated to new metaphors, updated those connections with the identification of an emerging structure, i.e. the blend, to indicate the elaboration of a new emerging concept through integration:

Metaphor is a salient and persuasive cognitive process that links conceptualization and language. It depends crucially on a cross-space mapping between two inputs (the Source and the Target). This makes it a prime candidate for the construction of blends, and indeed we find that blended spaces play key role in metaphorical mappings. That is, in addition to the familiar Source and Target of metaphorical projection, blends are constructed in which important cognitive work gets accomplished. [Fauconnier 1997: 168] 
12 As such, both cognitive theories partook of a new perception of the world through metaphor, either analogically or creatively. The development of a new concept or the understanding of one concept in terms of another fuel the perceptive power of metaphor.

13 Along with perceptive skills, metaphor permits popularisation when it makes knowledge more accessible. Popularisation of knowledge is made obvious when an abstract domain is perceived in terms of a concrete domain as suggested by the recurrent 'journey' metaphor: "History is a ribbon, always unfurling. History is a journey. And as we continue our journey, we think of those who traveled before us" [Reagan 1985]. If the vulgarisation aspect of metaphor has increased recently, it can be found in Aristotle's writings:

[Aristotle] stresses the cognitive value of these metaphors, claiming that they are lucid and that they convey truths about the world. He also stresses their pedagogical value: metaphors tell us things about the world which we did not understand beforehand, and the learning process is extremely enjoyable. People are attracted to metaphors precisely because they learn new things from them, seeing connections where previously they had not seen any. [Mahon 1999: 75-76]

14 The popularisation value of metaphor can be undermined by the risk of oversimplification. The attempt to simplify or make in-depth notions more accessible can be a flaw if the initial message is diverted or over-simplified, i.e. empty of its genuine essence. ${ }^{4}$ What were originally the binding powers (mapping) or the blending powers (integration) of the metaphor should not degrade into 'blinding powers'. The co-speaker or the audience could certainly be blinded by an extended metaphorical speech.

\subsection{Political powers}

15 In a political speech, the power to explain is often merged with the power to convince. ${ }^{5}$ Besides explanation, metaphor is useful for persuasion. As an element of rhetoric, in the Aristotelian view, metaphor is aimed at persuading. In that sense, it appears as an acting process since it potentially has effects on people:

If we are right in suggesting that our conceptual system is largely metaphorical, then the way we think, what we experience, and what we do everyday is very much a matter of metaphor. [Lakoff \& Johnson 1980: 3]

16 The power to convince people is fuelled by the power of memory and the power of recycling. This is made quite obvious in political speeches when the orator needs to refer to established metaphors to reassure the audience. The use of lexicalised metaphors, dead metaphors, conventional metaphors or pre-conceived metaphors is recurrent in political discourse for the necessary transition from old patterns to new perceptions. As a transitional moment, as an in-between period in the political agenda, the inaugural address appeals to the power of memory through worn-out metaphors being the result of de-metaphorisation:

Much of the history of every language is a history of demetaphorizing of expressions which began as metaphors gradually losing their metaphorical character. [Halliday 1994: 348]

17 As such, well-established metaphors, reminiscent of cultural preconceptions of the mind, calling on cognitive prerequisites, play a key role in reassuring the audience made of citizens. The power of recycling is closely linked to the power of memory, since recycling means using worn-out metaphors to develop new metaphors through remetaphorisation:

La réanimation d'une métaphore morte est une opération positive de délexicalisation qui équivaut à une nouvelle production de métaphore, donc de sens 
métaphorique. [...] Loin donc que le concept de métaphore s'avère n'être que l'idéalisation de sa propre métaphore usée, le rajeunissement de toutes les métaphores mortes et l'invention de nouvelles métaphores vives qui redécrivent la métaphore permettent de greffer une nouvelle production conceptuelle sur la production métaphorique elle-même. [Ricœur 1975: 370-373]

Recycling metaphors appears as a good way to establish a transition from old political models to new ones. The transition is soft since the worn-out part of the metaphor coexists with the new part of it. It is a smart way to deal with the past while getting rid of it to impose new models. As a political bridge over the past and the future, the inaugural address seems to correspond well to the recycling of metaphors: "Guided by the ancient vision of a promised land, let us set our sights upon a land of new promise" [Clinton 1997].

Metaphor as the art of persuasion based on memory and recycling is obvious in political addresses since the new president aims to invite citizens to share his views on America. Yet, the power to convince can slip into an imprisonment of the mind ${ }^{6}$ of the audience and metaphor can fail when it turns into a trap of the critical mind. ${ }^{?}$

\section{The metaphors of power}

After this overview of the powers of metaphor through a range of metaphorical processes (resemblance through mapping, integration through blending or conflictual power) our task is now to explore the metaphors of power in a corpus composed of American inaugural addresses from 1933 to 2013. What is the representation of power expressed by metaphors? How is it fuelled by an appeal to metaphors? Does metaphor always target the same sort of authority? From natural to human powers, from collective to personal powers, from worn-out to unexpected powers, the study of metaphor will give a perception of the power conveyed by inaugural addresses.

\subsection{Powerful nature}

21 We turn now to the analysis of the expression of the executive power epitomised in a series of presidential addresses. More than the human powers scattered amongst the political discourse, Mother Nature seems powerful when it comes to expressing a political perspective.

\subsubsection{Four elements}

Resorting to nature is recurrent in political discourse to explain positive or negative changes, general political trends, historical periods, a fragile economy or powerful leadership.

Amongst the four elements composing nature, air is the most pertinent domain in the expression of political change. Political change can be subtle ('breeze, clouds') or violent ('hurricane, storm') reaching its zenith with the tempest. The metaphorical process of assimilation (POLITICS IS METEOROLOGY) is pertinent here between a political atmosphere and a meteorological atmosphere. The change of weather remarkably forecast by the wind echoes the change of general political trend for the better ('a new breeze, lifting of 'mist') yet often for the worst ('fog, hurricane of disaster, raging storms') culminating in a mournful seasonal description with B. Obama's 'winter' of hardship (11). 
(1) The problems of our common welfare to be solved by the winds of chance and the hurricanes of disaster [Roosevelt, 1937]

(2) The moral climate of America [Roosevelt, 1937]

(3) No nation, however old or great, escapes this tempest of change [Eisenhower, 1957]

(4) Thus across all the globe there harshly blow the winds of change [Eisenhower, 1957]

(5) We seek peace, knowing that peace is the climate of freedom [Eisenhower, 1957]

(6) We rode through the storm with heart and hand [Jefferson quoted by Reagan, 1985]

(7) For a new breeze is blowing [Bush, 1989]

(8) There are times when the future seems thick as a fog; you sit and wait, hoping the mists will lift [Bush, 1989]

(9) Do you not think an angel rides in the whirlwind and directs this storm? [Bush, 2001]

(10) The oath is taken amidst gathering clouds and raging storms [Obama, 2009]

(11) In this winter of our hardship [Obama, 2009] various states of water are well known to describe the mind or external objects of the self, such as politics. Positive abstract notions ('freedom, faith, justice, democracy, peace, prosperity') which belong to the political sphere are thus abandoned to the waters ('currents, tide, river, ocean, sea, water'), often for the worse, except for some abatement ('ebbing tide, an ebb and flow'). Water, in political terms is seen as threatening ('raging sea, icy currents') or beneficial with 'rising tides' or 'still waters' (18).

(12) The means of exchange are frozen in the currents of trade [Roosevelt, 1933]

(13) Freedom is an ebbing tide [Roosevelt, 1937]

(14) We can turn rivers in their courses, level mountains to the plains. Oceans and land and sky are avenues for our colossal commerce [Eisenhower, 1953]

(15) America's faith in freedom and democracy was a rock in a raging sea [Bush, 2001]

(16) History had an ebb and flow of justice [Bush, 2005]

(17) When soldiers died in wave upon wave for a union based on liberty [Bush, 2005]

(18) The words have been spoken during rising tides of prosperity and the still waters of peace [Obama, 2009]

(19) Let us brave once more the icy currents and endure what storms may come [Obama, 2009]

Earth is less-referred to as a political transfer. Yet the lexicalised metaphor of the mountain to cross, illustrating difficulty, remains a common image in the political domain. The privative prefix un- ('uncrossed, unclimbed') highlights the difficulty to reach a new political step in America's ground.

(20) It [America] is the uncrossed desert and the unclimbed ridge [Johnson, 1965]

(21) But there are many mountains yet to climb [Reagan, 1985]

(22) What the cynics fail to understand is that the ground has shifted beneath them [Obama, 2009] 
Fire as the last of the four elements conveys various types of metaphors in a political speech. From a spark to the flames, the whole range of fire gives birth to different interpretations, either positive or negative. The smaller the fire ('spark, candle'), the better. Yet the expression fire, used metaphorically, can be ambiguous since G.W. Bush appealed to the same metaphor to evoke the 9/11 events ('day of fire') and the aftermath ('this untamed fire of freedom') in his 2005 inaugural address. This example is a good illustration of the semic perspective on metaphor when different semantic traits are used in different situations to express different meanings. If the first use of the term 'fire' in (26) could also be understood as a syllepsis since the ambiguity remains - the literal meaning of a real fire (real flames on 9/11) and a metaphoric meaning (conveyed by the expression 'day of fire', attack on 9/11) coexist - the second use of term in (27) is obviously metaphoric with the personification of fire with 'untamed' and the prepositional phrase 'of freedom'. Yet, both metaphorical uses express different meanings, contrary meanings, as the first 'fire' is seen as negative (+ explosion) compared to the second which is perceived as positive (+ light). Different semantic traits are thus conveyed in 'fire' according to the targeted meaning of the metaphor.

(23) There must appear the spark of hope, the hope of progress or there will surely rise at last the flames of conflict [Eisenhower, 1957]

(24) May the light of freedom, coming to all darkened lands, flame brightly until at last the darkness is no more [Eisenhower, 1957]

(25) Like a candle added to an altar-brightens the hope of all the faithful [Johnson, 1965]

(26) And then there came a day of fire [Bush, 2005]

(27) And one day, this untamed fire of freedom will reach the darkest corners of our world [Bush, 2005]

\subsubsection{The vegetal power. the power to grow?}

The use of the vegetal to refer to economy in politics is well spread in political speeches. Most of the metaphors have become dead or lexicalised through language. From birth to death, from 'roots' to 'leaves' and 'fruits', the gradient of lexicalisation is visible in the political speech. From 'seeds' ('a seed upon the wind') to 'fruits' ('the fruits of the land'), from alive metaphors to conventional metaphors, the vegetal metaphor highlights lexicalisation where the initial conflict is no longer perceived. The verb 'grow' (29) is a good illustration of the lexicalisation phenomenon since the genuine vegetal meaning has undergone semantic bleaching. 'Flourish' (39) and 'root' (31) as verbs appear as semilexicalised metaphors due to the greater use of those terms while referring to the economy. Such examples which express the power of nature to grow, are interestingly borrowed by politicians to express the power of America to keep on growing: economically, democratically, in strength, etc. It is noticeable that the metaphoric withering vegetal is only used for elements of the past: '[past] industrial enterprise', 'old ways', 'old [totalitarian] ideas'. Recourse to the vegetal to express political concerns partakes of the metaphoric gardening of America ('uprooting'), with the president in the role of the gardener.

(28) The withered leaves of industrial enterprise [Roosevelt, 1933]

(29) No, democracy is not dying. We know it because we have seen it revive and grow [Roosevelt, 1941]

(30) May we grow in strength [Eisenhower, 1957] 
(31) Yet this peace we seek cannot be born of fear alone: it must be rooted in the lives of nations [Eisenhower, 1957]

(32) Everywhere we see the seeds of the same growth that America itself has known [Eisenhower, 1957]

(33) Shaking old values and uprooting old ways [Johnson, 1965]

(34) If we keep its terms, we shall flourish [Johnson, 1965]

(35) The fruits of the land [Johnson, 1965]

(36) The totalitarian era is passing, its old ideas blown away like leaves from an ancient, lifeless tree [Bush, 1989]

(37) Now it is a seed upon the wind, taking root in many nations [Bush, 2001]

(38) And we will act not only to create new jobs but to lay a new foundation for growth [Obama 2009]

(39) We pledge to work alongside you to make farms flourish [Obama, 2009]

\subsubsection{The animal power. the power to dominate?} obvious. The zoomorphic metaphor [Tournier 2004: 141] is quite revealing of the power at stake. The choice of an animal to coin a metaphor is not innocent and even less so when it comes to politics. ${ }^{8}$ The reference to 'ostriches' or 'dogs' in Roosevelt's comparison (40) conveys the power of hierarchisation as a dog is proverbially the inferior of man, as an ostrich is proverbially afraid of reality. Reversely, the use of the 'tiger' as a metaphor for Russia, coined by Kennedy, illustrates the potential danger of the tiger, apparently tamed but waiting to pounce and devour its former master ('ended up inside'). Johnson's metaphor to assimilate men to 'ants', depicts another type of power, which seems to be the power of organisation and cooperation. Such an example is a good illustration of the integrative view on metaphor. The blending theory indeed appears quite explicitly with Johnson's example (42) since the reading of the sentence mimics the selective projections between mental spaces to reach the blend ('I do not believe that' [it is]... 'It is'), the emerging structure of metaphor. Through such an example, the targeted meaning is not the 'sterile battalion' but the 'trying and gaining' aspect of the ants' work. The selective process of the integrated metaphor is made clear by the reading: the conflictual analogy ${ }^{9}$ is focused on the power to organise and not giving up. Those three examples have shown the usefulness of the zoomorphic metaphors, in establishing power, whether it relates to domination, hierarchy or organisation.

(40) We have learned that we must live as men and not as ostriches, nor as dogs in the manger [Roosevelt, 1945]

(41) Those who foolishly sought power by riding the back of the tiger ended up inside [Kennedy, 1961]

(42) I do not believe that the Great Society is the ordered, changeless, and sterile battalion of the ants. It is the excitement of becoming - always becoming, trying, probing, falling, resting, and trying again - but always trying and always gaining [Johnson, 1965]

\subsection{The power of men: from many to one ( $A$ pluribus unum)}

\subsubsection{Collective power}

The very last example of ants as a metaphor for power of organisation calls upon the collective power of men. Very often, American presidents appeal to men as a workforce, a collective power to face the enemy or to build a better country. 


\subsubsection{Military powers: the power to fight} delivered by American presidents. ${ }^{10}$ It is no wonder as WWII and the Cold War cast a shadow over our corpus. It is no wonder, either, if we take into account the importance of the industry of war to the American economy and that war is often an electoral asset for American elections. ${ }^{11}$ The military metaphors reflect the power of men to fight for their country against the 'enemy'. Indeed, attack metaphors ('the lines of attack, vigorous action, fight for total victory, brutal attacks, will be conquered, fight our wars, marshaled, weapon') are numerous compared to defence metaphors. The latter ('fortress, shelter') are only coined to be negated and assimilated to a 'prison' in Eisenhower's 1957 speech (63). As such, military metaphors illustrate the power of attack, not the power of defence. Besides, collective power is often rooted in those metaphors thanks to a specific lexis referring to a collectivity of men ('trained and loyal army, this great army, enemies, allies, massed, fight our wars, marshaled'). Finally, the evolution of military metaphors is worthy of note since they seem to be reserved for periods of war: WWII and the Cold War. After 1989, no explicit mention of military metaphors is yet to be found in inaugural addresses, which could either correspond to a peace period or rather a change in war (a focus on terrorism), then a change in military powers.

(43) These are the lines of attack [Roosevelt, 1933]

(44) We must move as a trained and loyal army willing to sacrifice for the good of a common discipline [Roosevelt, 1933]

(45) I assume unhesitatingly the leadership of this great army of our people dedicated to a disciplined attack upon our common problems [Roosevelt, 1933]

(46) In their need they have registered a mandate that they want direct, vigorous action [Roosevelt, 1933]

(47) As today we work and fight for total victory in war [Roosevelt, 1945]

(48) The first half of this century has been marked by unprecedented and brutal attacks on the rights of man [Truman, 1949]

(49) Not only against their human oppressors, but also against their ancient enemies - hunger, misery, and despair [Truman, 1949]

(50) Our allies are the millions who hunger and thirst after righteousness [Truman, 1949]

(51) We sense with all our faculties that forces of good and evil are massed and armed and opposed as rarely before in history [Eisenhower, 1953]

(52) But this peaceful revolution of hope cannot become the prey of hostile powers [Kennedy, 1961]

(53) A struggle against the common enemies of man: tyranny, poverty, disease and war itself [Kennedy, 1961]

(54) I have believed that this injustice to our people, this waste of our resources, was our real enemy [Johnson, 1965]

(55) But change has given us new weapons. Before this generation of Americans is finished, this enemy will not only retreat, it will be conquered [Johnson, 1965]

(56) And we will fight our wars against poverty, ignorance, and injustice, for those are the enemies against which our forces can be honorably marshaled [Carter, 1977]

(57) As for the enemies of freedom, those who are potential adversaries [Reagan, 1981] 
(58) It is a weapon [moral courage of free men and women] that we as Americans do have [Reagan, 1981]

(59) For freedom is our best ally [Reagan, 1985]

\subsubsection{Architectural powers: the power to build}

31 The power to build is as frequent as the power to fight in American presidents' speeches. The architectural metaphor presents a various range of sub-categories: types of building ('temple, fortress, shelter, cathedral, bastion'), elements of the house ('doorstep, stone, threshold, front porch, marble steps, pillars'), construction process ('building, construct, rebuild'), demolition process ('bring down the walls, torn down the barriers'), passage process ('bridge, door'). In the Conceptual Metaphor Theory, the underlying conceptual metaphor could be the following HOPE IS CONSTRUCTION. Yet hope can be built only with a collective impulse. The workforce of men as a collectivity or a community is embodied in architectural metaphors. The collective power to build a new world is well anchored in Nixon's 1969 speech 'each of us raising it one stone at a time' (65), or Clinton's 1997 address 'let us build our bridge' (76).

(60) Plenty is at our doorstep [Roosevelt, 1933]

(61) The money changers have fled from their high seats in the temple of our civilization [Roosevelt, 1933]

(62) The building of a peace with justice in a world where moral law prevails [Eisenhower, 1957]

(63) No nation can longer be a fortress, lone and strong and safe. And any people, seeking such a shelter for themselves, can now build only their own prison [Eisenhower, 1957]

(64) Underneath the clamor of building [Johnson, 1965]

(65) With these, we can build a great cathedral of the spirit - each of us raising it one stone at a time [Nixon, 1969]

(66) As we meet here today, we stand on the threshold of a new era of peace in the world [Nixon, 1973]

(67) Let us continue to bring down the walls of hostility which have divided the world for too long, and to build in their place bridges of understanding [Nixon, 1973]

(68) Let us build a structure of peace in the world [Nixon, 1973]

(69) That we had torn down the barriers that separated those of different race and religion, and where there had been mistrust, build unity, with a respect for diversity [Carter, 1977]

(70) This last and greatest bastion of freedom [Reagan, 1981]

(71) We meet on democracy's front porch [Bush, 1989]

(72) Great nations of the world are moving toward democracy through the door to freedom. Men and women of the world move toward free markets through the door to prosperity [Bush, 1989]

(73) A vow made on marble steps [Bush, 1989]

(74) Our people have always mustered the determination to construct from these crises the pillars of our history [Clinton, 1993]

(75) While America rebuilds at home [Clinton, 1993]

(76) Yes, let us build our bridge, a bridge wide enough and strong enough for every American to cross over to a blessed land of new promise [Clinton, 1997] 


\subsubsection{From neighbours to friends: the power to peace} relationships. Contrary to military powers, those metaphors tend to express solidarity and a will to peace. Interestingly enough, from Roosevelt's first address in 1933 to Obama's first speech in 2009, the vocabulary has evolved from 'neighbor' (77) to 'friend' (79). The underlying metaphor A COUNTRY IS A NEIGHBOUR has turned into A COUNTRY IS A FRIEND. The peace process has evolved in developing a more generous relationship between America and the other states, yet a more distant relationship with nations.

(77) The neighbor who respects his obligations and respects the sanctity of his agreement in and with a world of neighbors [Roosevelt, 1933]

(78) They are making their country a good neighbor among the nations [Roosevelt, 1937]

(79) America is a friend of each nation [Obama, 2009]

\subsubsection{Chorus powers: the power to share}

Another recurrent collective pattern establishing the power of men is the motif of the chorus. The musical metaphor to express a collective force is the chorus where the merging of different voices gives birth to a harmony. The multitude of voices brings strength to unity. The acknowledgement of a chorus by American presidents, especially W. Clinton, is a way to confer power to individuals because of the merging into one song: 'the chorus of America' (80). Then, the power to share becomes powerful when in tune ('the song of our industry, the music of our time, the voice of the people').

(80) The air rings with the song of our industry - rolling mills and blast furnaces, dynamos, dams and assembly lines - the chorus of America the bountiful [Eisenhower, 1957]

(81) Though we marched to the music of our time, our mission is timeless [Clinton, 1993]

(82) You have raised your voices in an unmistakable chorus [Clinton, 1993]

(83) We have heard the trumpets. We have changed the guard [Clinton, 1993]

(84) We will have reformed our politics so that the voice of the people will always speak louder than the din of narrow interests [Clinton, 1997]

Like 'the chorus of America' which remains ambiguous in terms of the tension between plural voices and a single tune, the term 'America', often spoken in inaugural addresses, can be understood as a collective plurality or a single entity, captured, of course in the republican motto: A pluribus unum. The personification of America expressed by many presidents assigning a body ('body, heart, face, clothe, feed') and a mind ('mind, instruct, inform') to the country, highlights the perception of America as an ontological unit (age old representation of the nation (88) as a living organism (86), working together). Likewise, from initial diversity to unity, the powers of America seem no longer to belong to the power of men but to the power of a single man.

(85) It is not enough to clothe and feed the body of this Nation, to instruct, and inform its mind [Roosevelt, 1941]

(86) The heart of America [Eisenhower, 1953]

(87) It is to make kinder the face of the Nation [Bush, 1989]

(88) In the year of America's birth [Obama, 2009] 


\subsubsection{The powers of a single man}

Despite the recurrent use of the pronoun 'we' used by all American presidents to express America's powers as a collective power, the metaphors we have studied so far are often tainted by traces of personal authority. The executive power, through the president's single voice, often implicitly shows through the text. The subtle change in personal pronouns with a displacement from 'we' to 'I' (96), or the subtle shifting of powers assigned to one man, the president, when it comes to metaphors of power, are elements which bring out an underlying meaning which allocates powers to one man only. The president can be seen in turn as the chief, the architect, the father, the leader, the captain, the surgeon or the master:

The commander in chief ${ }^{12}$

(89) I assume unhesitatingly the leadership of this great army of our people dedicated to a disciplined attack upon our common problems [Roosevelt, 1933]

The architect of America

(90) While America rebuilds at home [Clinton, 1993]

The father of the family ${ }^{13}$

(91) Because Washington remains the Father of our Country [Bush, 1989]

The lied/er of a group

(92) We need harmony; we've had a chorus of discordant voices [Bush, 1989]

The captain of his own ship ${ }^{14}$

(93) America will remain the anchor of strong alliances in every corner of the globe [Obama, 2013]

(94) After the shipwreck of communism come years of relative quiet [Bush, 2005]

The surgeon of America ${ }^{15}$

(95) I want to thank my predecessor for all he has done to heal our land [Carter, 1977]

(96) We have known divisions, which must be healed to move forward in great purposes, and I will strive in good faith to heal them [Bush, 2005]

'The master of its own house' ${ }^{16}$

(97) And let every other power know that this Hemisphere intends to remain the master of its own house [Kennedy, 1961]

(98) We would not admit that we could not find a way to master economic epidemics just as, after centuries of fatalistic suffering, we had found a way to master epidemics of disease [Roosevelt, 1937]

(99) We seek no dominion over our fellow man, but man's dominion over tyranny and misery [Johnson, 1965]

If, as claimed by J.F Kennedy, America "intends to remain the master of its own house", most American presidents admit that this wish cannot be fulfilled without the will of God. After the collective powers of men, after the individual powers of a single man, come the powers of the divine. From community to individuality, from individuality to uniqueness, metaphors of power differ.

\subsection{The power of the divine}

The powers conferred to God by most American presidents regularly come at the end of their inaugural addresses. The appeal to God as a closure of the address appears as a reminder that, without the will of God, no power is given to the president (cf. the vow). As 
if, without God's blessing, the power conferred on the president and on the people would be nullified. In that sense, the command of God comes as the paramount power over man. This regular $\operatorname{coda}^{17}$ in inaugural addresses is the locus for various metaphors of divine power.

God as guide: the power to lead

(100) May He guide me in the days to come [Roosevelt, 1933]

(101) Seeking Divine guidance [Roosevelt, 1933]

(102) Guide our feet into the way of peace [Roosevelt, 1937]

(103) We beseech God's guidance [Eisenhower, 1953]

God as saviour: the power to protect

(104) With God's help, the future of mankind will be assured in a world of justice, harmony, and peace [Truman, 1949]

(105) Asking His blessing and His help, but knowing that here on earth God's work must truly be our own [Kennedy, 1961]

(106) To believe that together with God's help we can and will resolve the problems which now confront us [Reagan, 1981]

(107) We raise our voices to the God who is the Author of this most tender music. And may He continue to hold us close [Reagan, 1985]

(108) And now, each in our own way and with the God's help, we must answer the call [Clinton, 1993]

(109) May God strengthen our hands for the good work ahead [Clinton, 1997]

(110) May God bless you, and may He watch over the United States of America

[Bush, 2005]

God as redeemer: the power to forgive

(111) God bless you. And God bless the United States of America [Bush, 1989]

(112) And with eyes fixed on the horizon and God's grace upon us [Obama, 2009]

(113) May He forever bless these United States of America [Obama, 2013]

God as providence: the willing power

(114) As Americans, we go forward, in the service of our country, by the will of God [Roosevelt, 1941]

(115) To the achievement of His will to peace on earth [Roosevelt, 1945]

(116) Our confidence in the will of God and the promise of man [Nixon, 1969]

All powers dedicated to God (leading men, protecting men, forgiving men) via metaphors or allegories,${ }^{18}$ remind us of the impact of religion in the United States. The call on God and on His unique powers over men ('guide our feet') [Roosevelt, 1937] or upon one man ('May He guide $m e^{\prime}$ ) [Roosevelt, 1933] are a good illustration of the use of metaphors by American presidents to endorse power in a world where power is the landmark of a society.

\section{Toward an extension of executive powers?}

Various metaphors expressing power, either a collective force or an individual leadership, have been looked upon through a series of inaugural addresses of American presidents from 1933 to 2013. Power has been exposed through metaphors of nature, men or even God. We may now turn to the appreciation of executive powers through inaugural addresses. How representative is the executive political power throughout inaugural addresses? If the president's power is visible though metaphors and speech, is an extension of his powers visible? The acknowledgement of an extension of the executive powers in the United States has been stated by many: 
L'histoire des rapports de force entre les trois pouvoirs américains, législatif, exécutif et judiciaire, pour les citer dans l'ordre constitutionnel, est celle d'une lente mais inexorable montée en puissance de la présidence. [Michelot 2008: 1]

Is such a statement observable in the American presidents' speeches? Has the representation of American executive power gradually increased over the period studied?

\subsection{An extension of powers?}

41 A lexical search for the item "power*19 in all addresses from our corpus has revealed a total of 73 occurrences. Yet the item 'power*' remains far behind the top ranking words such as 'world' (185 items), 'people' (168 items), 'new' (150 items), 'America' (120 items) or even 'freedom' (117 items). An in-depth analysis has shown that the item covers various expressions of power. The singular form (52 occurrences) is often referred to with various types of powers: 'power to govern', 'power to stop evil', 'power to do good' [Roosevelt, 1937] whereas the plural form ( 7 occurrences) opens the way to a greater target: 'powers of united action', 'powers of government', 'autocratic powers' [Roosevelt, 1937]. The adjectival form 'powerful' (12 occurrences) and the verbal forms 'power' (1 occurrence) or 'empower' ( 1 occurrence) both used by B. Obama [2013] alternatively fuel the presence of specific powers even if some of them are not ruled by the executive but are dedicated to citizens or unnamed dark forces. ${ }^{20}$

The word 'power' and its derived forms, either prefixed or suffixed, have been differently used by various presidents and by the same president. The major discrepancy between two presidents stands between J.F. Kennedy's address ( 9 occurrences) and his successor L.B. Johnson's (0 occurrences). Since Johnson's address, the use of the item 'power' has slowly but gradually increased with an exception for G.W. Bush's addresses (Figure 1). More strikingly, a great variation in the use of the same item can be found with the same president. After he used the 'power' item 10 times in his second inaugural address, F.D. Roosevelt did not use it at all in his following speeches to the nation.

Figure 1. A quantification of 'power' occurrences through TextSTAT

\begin{tabular}{|l|l|l|l|}
\hline Inaugural addresses & $\begin{array}{l}\text { Occ. of } \\
\text { 'Power*' }\end{array}$ & $\begin{array}{l}\text { Occ. of } \\
\text { 'I' }\end{array}$ & $\begin{array}{l}\text { Occ. of } \\
\text { 'we' }\end{array}$ \\
\hline & 3 & 19 & 26 \\
\hline 33_Franklin D. Roosevelt/ Inaugural Address & 3 & 16 & 47 \\
\hline 37_Franklin D. Roosevelt/ Inaugural Address & 10 & 2 & 31 \\
\hline 41_Franklin D. Roosevelt/ Third Inaugural Address & 0 & 3 & 25 \\
\hline 45_Franklin D. Roosevelt/ Inaugural Address & 0 & 10 & 59 \\
\hline 49_Harry S. Truman/ Inaugural Address & 2 & 3 & 66 \\
\hline 53_Dwight D. Eisenhower/ Inaugural Address & 4 & 4 & 50 \\
\hline 57_Dwight D. Eisenhower/ Second Inaugural Address & 5 & & \\
\hline
\end{tabular}




\begin{tabular}{|c|c|c|c|}
\hline 61_John F. Kennedy/Inaugural Address & 9 & 3 & 30 \\
\hline $\begin{array}{l}\text { 65_Lyndon B. Johnson/ The President's Inaugural } \\
\text { Address }\end{array}$ & 0 & 15 & 34 \\
\hline 69_Richard Nixon/Inaugural Address & 1 & 21 & 67 \\
\hline $\begin{array}{l}\text { 73_Richard Nixon/ Oath of Office and Second Inaugural } \\
\text { Address }\end{array}$ & 2 & 14 & 47 \\
\hline 77_Jimmy Carter/Inaugural Address & 2 & 6 & 43 \\
\hline 81_Ronald Reagan/Inaugural Address & 2 & 19 & 49 \\
\hline 85_Ronald Reagan/Inaugural Address & 3 & 11 & 62 \\
\hline 89_George Bush/ Inaugural Address & 3 & 24 & 57 \\
\hline 93_William J. Clinton/ Inaugural Address & 5 & 7 & 52 \\
\hline 97_William J. Clinton/ Inaugural Address & 5 & 4 & 41 \\
\hline 2001_George W. Bush/ Inaugural Address & 4 & 11 & 46 \\
\hline 2005_George W. Bush/ Inaugural Address & 3 & 8 & 37 \\
\hline 2009_Barack Obama/Inaugural Address & 5 & 3 & 62 \\
\hline 2013_Barack Obama/Inaugural Address & 5 & 4 & 70 \\
\hline
\end{tabular}

One of the most striking elements of executive power is nonetheless to be found in F.D. Roosevelt's inaugural address in 1933. Power as an instrument of fear against the Congress unveils the conceptual metaphor POWER IS AN INSTRUMENT OF FEAR: "But in the event that the Congress shall fail to take one of these two courses, and in the event that the national emergency is still critical, I shall not evade the clear course of duty that will then confront me. I shall ask the Congress for the one remaining instrument to meet the crisis - broad Executive power to wage a war against the emergency, as great as the power that would be given to me if we were in fact invaded by a foreign foe" [Roosevelt, 1933]. Such an example illustrates how power can be metaphorised to reinforce the powerful position of the President towards the Congress.

\subsection{Toward the omnipresence of the leader?}

The general lexical analysis of pronouns used in inaugural addresses goes against the hypothesis that the same speeches would be a mirror for the gradual omnipresence of the American leader. The analysis of the corpus as a whole has indeed revealed a great proportion of pronouns dedicated to the collectivity compared to those assigned to the individual, i.e., the President. The number of occurrences of the pronoun 'we' (1001) is greater than the number of the personal pronoun 'I' (202). The possessive pronouns mimic this general trend with 931 occurrences of 'our' compared to 93 occurrences of 
'my'. This is reinforced by the object pronouns 'us' (280) in contrast with the pronoun 'me' (28 occurrences). The total number of pronouns dedicated to the audience as 'you' (195) is slightly inferior to the pronoun 'I' (202). This last figure, added to the regular recourse to the individual 'we', tends to confirm the emphasis on the president's personal power especially when he addresses an audience composed of citizens.

The discrepancy amongst various presidents is clear if we compare the extremes. G. Bush stands as the most 'self-centred' president in his 1989's speech (24 occurrences of 'I'), before R. Nixon's first address in 1969 (21 occurrences of 'I') whereas B. Obama's last inaugural address to the people [2013] is the most collective one in our corpus with a score of 70 occurrences of 'we' (Figure 2). In the recent years, G.W. Bush's speeches epitomised the extensive executive powers with two linguistic ruptures in terms of pronouns: he is the only president with a score of more than ten ' $\mathrm{I}$ ' amongst the last six presidents (Clinton to Obama) and the only president since Johnson (1965) to use fewer than forty occurrences of 'we'. Even if the evolution of quantification of pronouns in inaugural speeches remains uneven throughout the years and despite two contradictory extremes (Roosevelt and Obama), a slight tendency of the extension of the presidential powers through addresses is noticeable.

Figure 2. An evolution of 'power', 'I', and 'we' occurrences through TextSTAT

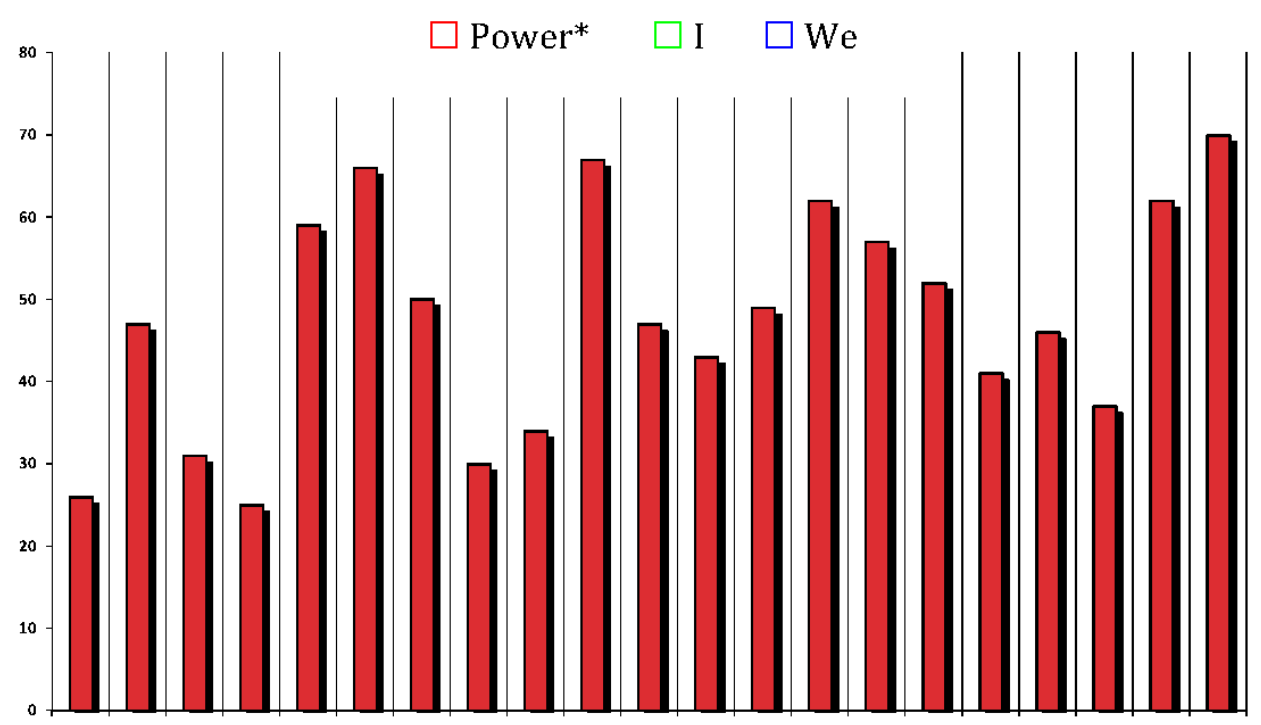

Such a trend is exemplified in the evolution of metaphors of power spoken by the same President W. Clinton. In his first address to the nation, W. Clinton insisted upon the collective power of ideas through the conceptual metaphor STRENGTH IS POWER: "But our greatest strength is the power of our ideas, which are still new in many lands. Across the world we see them embraced, and we rejoice" [Clinton, 1993]. Conversely, in his second speech, he emphasised his personal executive power as a President through the use of the possessive 'my' and the metonymic process OFFICE AS PRESIDENT: “To that effort I pledge all my strength and every power of my office. I ask the Members of Congress here to join in that pledge" [Clinton, 1997]. 


\subsection{Increasing metaphors of leadership?} but also a matter of metaphor. Some metaphors more than others are quite telling of the powers envisaged by the president for the president. The choice of the executive branch to coin such creative metaphors is germane to its re-assertion of personal powers. The power of the painter suggested by F.D. Roosevelt: "It is not in despair that I paint you that picture. I paint it for you in hope because the Nation, seeing and understanding the injustice in it, proposes to paint it out" [Roosevelt, 1937] parallels the power of the singer instigated by G. Bush: "And we must ensure that America stands before the world united, strong, at peace, and fiscally sound. But of course things may be difficult. We need to compromise; we've had dissension. We need harmony; we've had a chorus of discordant voices" [Bush, 1989]. Yet the power of the writer is the most striking in the allowance of inscriptive powers to the president: "In this we Americans were discovering no wholly new truth; we were writing a new chapter in our book of self-government" [Roosevelt, 1937]; "Some see leadership as high drama and the sound of trumpets calling, and sometimes it is that. But I see history as a book with many pages, and each day we fill a page with acts of hopefulness and meaning. The new breeze blows, a page turns, the story unfolds. And so, today a chapter begins, a small and stately story of unity, diversity, and generosity shared, and written, together" [Bush, 1989]. The disguised collective pattern of writing history altogether is in fact rooted in a more personal power to write a chapter of history. In other terms, by coining such a metaphor, the President allows himself a power, the power of writing, but far more importantly the power to impose a certain vision of the world, a perception of the world. Insidiously, the coinage of a metaphor gives power to the coiner. By using metaphors, the speaker, the orator, i.e. the President, grants himself a power to shape the world. Processing metaphors can then be seen as an extension of personal powers.

\section{Conclusion}

Starting with the powers of metaphor in terms of decoration, perception or political action, and moving then to the metaphors of power subdivided into the powers of nature (seasonal metaphors, vegetal metaphors, animal metaphors), the powers of men (military metaphors, architectural metaphors), the powers of one man (captain metaphors, surgeon metaphors, master metaphors) or the powers of God (leader metaphors, saviour metaphors), we have attempted to demonstrate that the metaphor of power is multiple and is often underlying most metaphors spoken by American presidents in their inaugural addresses. The power to build, to fight, to grow are embodied in political addresses through metaphors, either conventional or creative. The executive power seems to gain from a supposedly collective workforce since the figure of the president as the master is often close behind. Along with the study of metaphors, an added lexical analysis (power, pronouns) has shown variations amongst presidents or between a first and second address of one president. If a gradual increase in the representation of executive powers is not obvious in the final analysis, the study of metaphors in inaugural addresses has nonetheless shown an uneven but undeniable extension of presidential powers. This pattern of progress marked by linguistic hiatuses mirrors what Galston named the Cycles of Executive Power in American history. ${ }^{21}$ Indeed, previous striking coined 
metaphors such as 'a city upon a hill' [Kennedy, 1961], 'the policeman of the world' [Roosevelt, 1904], represented a linguistic and historical landmark in the evolution of presidential powers.

\section{BIBLIOGRAPHY}

ARISTOTLE, Poetics, translation S. H. Butcher, London: Macmillan, 1950.

BOUVERESSE Jacques, Prodiges et vertiges de l'analogie, Paris: Raisons d'agir, 1999.

CICERO, De Oratore, translation A. Ernout, Paris: Editions des Belles Lettres, 1970.

DEGUY Michel, « Et tout ce qui lui ressemble... », in CHARBONNEL Nanine \& KLEIBER Georges (Eds.), La métaphore entre philosophie et rhétorique, Paris: 'linguistique nouvelle', Presses Universitaires de France, 1999: 17-31.

ECO Umberto, Sémiotique et philosophie du langage, Paris: 'Quadrige', Presses Universitaires de France, 2006, (1988).

FAUCONNIER Gilles, Mappings in Thought and Language, Cambridge: Cambridge University Press, 1997.

GALAND-HALLYN Perrine, " Art descriptif et argumentation dans la poésie latine ", in MEYER Michel \& LEMPEREUR Alain (Eds.), Figures et conflits rhétoriques, Bruxelles: Editions de l'Université de Bruxelles, 1990: 39-57.

GALSTON William, “Cycles of Executive Power”, in LACORne Denis \& VAÏsSE Justin (Eds.), La présidence impériale, Paris, Odile Jacob, 2007: 99-110.

HALLIDAY Michael Alexander Kirkwood, An Introduction to Functional Grammar, London, Arnold, 1994.

IYENGAR Shanto \& HAHN Kyu, "History versus Media Management as Determinants of Presidential Popularity: An Analysis of Unemployment and Terrorism”, in LACORNE Denis \& VAÏsSE Justin (Eds.), La présidence impériale, Paris: Odile Jacob, 2007: 146-160.

LAKOFF George, “The Contemporary Theory of Metaphor”, in ORTONY Andrew (Ed.), Metaphor and Thought, Second edition, Cambridge: Cambridge University Press, 1993: 202-251.

LAKOFF George \& JOHNSON Mark, Metaphors We Live By, Chicago and London: The University of Chicago Press, 1980, (Afterword, 2003).

MAHON James Edwin, “Getting your Sources Right: What Aristotle didn't Say”, in CAMERON Lynne \& Low Graham (Eds.), Researching and Applying Metaphor, Cambridge: 'Cambridge applied linguistics', Cambridge University Press, 1999: 69-80.

MELANDRI Pierre, «Temps de guerre, temps de la présidence ? ", in LACORNE Denis and VAÏsSE Justin (Eds.), La présidence impériale, Paris : Odile Jacob, 2007: 29-56.

MEYER Michel, Introduction à Rhétorique d'Aristote, Paris : ‘Classiques de poche', Le livre de poche, 1991. 
MICHELOT Vincent, L'empereur de la Maison-Blanche, Paris: Armand Colin, 2008, (2004).

PARRET Herman, « La rhétorique : heuristique et méthode chez Kant », in MEYER Michel and LEMPEREUR Alain (Eds.), Figures et conflits rhétoriques, Bruxelles : Editions de l'Université de Bruxelles, 1990: 104-114.

PRANDI Michele, Grammaire philosophique des tropes, Paris : ‘Propositions', Minuit, 1992.

RESCHE Catherine, «Le discours officiel du Président de la Réserve Fédérale américaine : entre transparence et propagande ", in BANKS David (Ed.), Aspects linguistiques du texte de propagande, Paris : L'Harmattan, 2005: 147-173

RICœUR Paul, La métaphore vive, Paris : 'Essais', Seuil, 1975.

SONTAG Susan, La maladie comme métaphore, Paris : Christian Bourgois, 1977, (2005).

TOURNIER Jean, Précis de lexicologie anglaise, Paris : Ellipses, 2004.

\section{NOTES}

1. See S. Iyengar and K. Hahn's chapter on The President as Communicator in Chief. [Iyengar \& Hahn 2007: 146-149]

2. «Aristote, pour sa part, fait de la métaphore la figure des figures, celle dont font usage les poètes pour illustrer ce qu'ils ont à dire comme pour charmer leurs auditeurs » [Meyer 1991: 36].

3. «La métaphore n'est pas seulement un instrument de plaisir mais aussi et surtout un instrument de connaissance " [Eco 2006: 158].

4. J. Bouveresse warns against the use of a metaphor which would transform a mere air de famille in a real identity. [Bouveresse 1999: 47]

5. Galland-Hallyn goes further by saying: "Les similitudes tendent à la fois à 'persuader' en faisant appel à la logique du lecteur (docere) et à 'séduire' par le recours à l'esthétique, à l'émotion (mouere)". [Galand-Hallyn 1990: 42]

6. « Tout discours, dans la mesure où il vise à gagner un auditoire à ce qui est dit, porte en lui une tentative de séduction, de persuasion qui, dans certains cas, peut évoluer en tentative de propagande (i.e. propagation de la foi)». [Resche 2005: 147]

7. «En se présentant comme un art de persuader, [la métaphore] risque fort de devenir un art de tromper et même d'ôter aux esprits leur liberté de jugement ». [Parret 1990: 105]

8. See G. Orwell's Animal Farm, 1945.

9. See M. Prandi [1992] for the perception of metaphor as a conflict.

10. The outbreak of war often means an extension in executive powers as stated by Madison: "War is in fact the true nurse of executive aggrandizement." [Galston 2007: 102]

11. " D'un côté, la guerre est absolument centrale à l'histoire et à la culture du pays, qui est non seulement né d'une guerre, mais s'est par la suite cimenté et étendu au travers de nombreuses opérations militaires. La gloire acquise dans ces dernières a souvent servi de tremplin à des carrières politiques ». [Melandri 2007: 29]

12. As stipulated by Art. II section 2 of the Constitution: "The President shall be Commander in Chief of the Army and Navy of the United States". The military metaphor focused on his own power then perfectly illustrates his personal power as Commander in Chief.

13. The authority dedicated to the President is made obvious by the metonymic process (the place for the function, i.e. Washington for the President) besides the metaphoric process (Washington as the Father of the Country).

14. In the same maritime metaphor, the positive 'anchorage' of America opposes the historical 'piracy' of America toward communism left 'shipwrecked'. 
15. If the President corresponds to the surgeon of America, his team should not be forgotten with numerous metaphors indicating the power to heal vested in the 'we': 'Second, we will continue our programs for world economic recovery' [Truman, 1949]; 'So we voice our hope and our belief that we can help to heal this divided world' [Eisenhower, 1957]; 'In a land of healing miracles' [Johnson, 1965]; 'The peace that comes 'with healing in its wings" [Nixon, 1969]; 'An economic recovery has begun' [Obama, 2013]. Such a healing power is used to counterbalance the disease metaphor (See Sontag 1977): 'They will demand a nation uncorrupted by cancers of injustice' [Roosevelt, 1937]; 'Not without the difference of opinion but without the deep and abiding divisions which scar the union for generations' [Johnson, 1965]; 'America has suffered from a fever of words' [Nixon, 1969]; 'The economic ills we suffer have come upon us over several decades' [Reagan, 1981]; 'It [drugs] may as well have been a deadly bacteria' [Bush, 1989]; 'Threatened by ancient hatred and new plagues' [Clinton, 1993].

16. Despite Bush's saying, 'Because no one is fit to be a master and no one deserves to be a slave' [Bush, 2005], the motif of the 'master' is recurrent in the Presidential representation of power or a more collective power.

17. The term coda is used since all Presidents must take the Oath on the Bible: 'Before he enter on the Execution of his Office, he shall take the following Oath or Affirmation: 'I do solemnly swear (or affirm) that I will faithfully execute the Office of President of the United States, and will do the best of my Ability, preserve, protect and defend the Constitution of the United States."[Art. II section 1]

18. Allegory is close to metaphor: «Avec l'allégorie, on se trouve face à un dédoublement de sens pour faire une vérité ». [Deguy 1999: 28]

19. The search for 'power*' through TextSTAT concordance software generates all derived forms of the word 'power': powers, powerful, empower, etc.

20. Nevertheless, our lexical analysis will take into account all aspects of powers without distinction of the agent or the benefactor since the spoken word always partakes of the notion of power.

21. See Cycles of Executive Power [Galston 2007: 99].

\section{ABSTRACTS}

Through the study of various American presidents' inaugural addresses, from F.D. Roosevelt's first address to B. Obama's second inaugural address, the powers of metaphor, either ornamental, cognitive, or political, will be highlighted before a thorough analysis of the metaphors of power, whether they be collective (military metaphors, architectural metaphors), individual (the president as the father, the master, the surgeon), or even divine. Conjointly taking metaphor and power into consideration will eventually help answer the following question: do power metaphors reflect the increasing executive powers conferred on the president over this period?

À travers l'étude des discours d'investiture des présidents américains, du premier discours de F.D. Roosevelt au dernier discours de B. Obama, les pouvoirs conférés à la métaphore, qu'ils soient d'ordre ornemental, cognitif ou politique, seront soulignés en prélude d'une analyse des métaphores du pouvoir, qu'il soit collectif (métaphores militaires, métaphores architecturales), individuel (le président assimilé au père, au maître, au chirurgien) ou encore divin. L'analyse conjointe de la métaphore et du pouvoir permettra enfin de répondre à la question suivante : les 
métaphores du pouvoir sont-elles le reflet d'un pouvoir exécutif grandissant au cours de cette période?

INDEX

Mots-clés: discours, exécutif, métaphore, politique, pouvoir

Keywords: discourse, executive branch, metaphor, politics, power

\section{AUTHOR}

\section{RÉMI DIGONNET}

Université Catholique de Lille, France

digonnet.remi@gmail.com 